ISSN 1392-3196 / e-ISSN 2335-8947

Zemdirbyste-Agriculture, vol. 100, No. 3 (2013), p. 261-268

DOI $10.13080 /$ z-a.2013.100.033

\title{
Antioxidative activity of azoles and their influence on barley (Hordeum vulgare L.) seedlings and flavonoid accumulation
}

\author{
Ilona JONUŠKIENĖ, Ingrida TUMOSIENĖ, Kristina KANTMINIENE், \\ Kęstutis RUTKAUSKAS, Zigmuntas Jonas BERESNEVIČIUS \\ Kaunas University of Technology \\ Radvilènų 19, Kaunas, Lithuania \\ E-mail: ilona.jonuskiene@ktu.lt
}

\begin{abstract}
This research was aimed at exploring the antioxidative activity of new azole compounds and their influence on barley (Hordeum vulgare L.) growth in vitro and changes of flavonoid content. Azole derivative 5-\{2-[(4-methylphenyl)amino]ethyl $\}-N$-phenyl-1,3,4-thiadiazol-2-amine showed the best radical scavenging property. The highest growth regulating activity was demonstrated by 3-(4-methylphenyl)-1-phenyl-3-\{2[5-(phenylamino)-1,3,4-thiadiazol-2-yl]ethyl $\}$ thiourea. The length of the barley shoots, which were exposed to this compound $\left(0.1 \mathrm{mg} \mathrm{l}^{-1}\right)$ increased by $42.7 \%$ in comparison with the control sample. Under its influence $\left(0.4 \mathrm{mg} \mathrm{l}^{-1}\right)$ barley roots were by $72.3 \%$ longer than the ones of the control sample. The highest antioxidative activity was determined for the barley seedlings, which were exposed to the same $N^{\prime}$-thiocarbamoyl-1,3,4-thiadiazole $\left(0.1 \mathrm{mg} \mathrm{l}^{-1}\right)$.
\end{abstract}

Key words: biological activity, metabolites, oxadiazole, thiadiazole.

\section{Introduction}

Antioxidants are widely studied for their capacity to protect organisms and cells from damage induced by oxidative stress. New compounds, either synthesized or obtained from natural sources, attract attention of the scientists searching for the active components which could prevent or reduce the impact of oxidative stress on cells. Exogenous chemicals and endogenous metabolic processes in human body or in food system might produce highly reactive free radicals, especially oxygen derived radicals, which are capable of oxidizing biomolecules and thus causing cell death and tissue damage. Free radical oxidative processes also play a significant role in pathogenesis. Cancer, emphysema, cirrhosis, atherosclerosis, and arthritis have all been correlated with oxidative damage. In addition, excessive generation of reactive oxygen species induced by various stimuli leads to a variety of pathophysiological abnormalities such as inflammation, diabetes, genotoxicity, and cancer (Ünver et al., 2011).

The flavonoids are a remarkable group of plant metabolites. No other class of secondary product has been credited with so many or such diverse-key functions in plant growth and development. Flavonoids are known to enhance tolerance to a variety of abiotic stressors, they are employed as agents of defense against herbivores and pathogens, and they form the basis for allelopathic interactions with other plant species. The past decade has witnessed resurgence in research activity on the functions of flavonoids in plants because of their elevated capacity for scavenging free radicals associated with various diseases (Andersen, Markham, 2006). A large number of tests measuring their antioxidative activity in vitro have been reported (Nijveldt et al., 2001).

Barley (Hordeum vulgare L.) is an important crop both for brewing and for animal feed. In addition to conventional breeding, in vitro culture is a useful technology for the improvement of barley quality (Hall, 1999). The antioxidant properties of phenolic compounds, including flavonoids, in grains have been associated with the health benefits attributed to these crops and the valueadded products derived from them. One of the richest sources of phenolics among the grains is barley. In beer, for example, $70 \%$ to $80 \%$ of the phenolic constituents originate from malted barley while the remaining 20\% to $30 \%$ come from the hops (Gerhäuser, 2005). The scavenging activity of barley phenolics against DPPH (1,1-diphenyl-2-picrylhydrazyl) and ABTS (2,2'-azinobis(3-ethylbenzothiazoline-6-sulphonic acid)) are comparable to a synthetic antioxidant BHT (butylated hydroxytoluene) (Ragaee et al., 2006). The flavone $C$-glycosides saponarin and luteorin have been found to be the major flavonoid antioxidants in young green barley leaves (Markham, Mitchell, 2003). The results of the investigation of the antioxidative and hypolipidemic effects of barley leaf essence in a rabbit model of atherosclerosis have suggested that this material can be utilised in the prevention of cardiovascular disease in which atherosclerosis is important (Yu et al., 2002).

Scientists in many different disciplines become more interested in new compounds, either synthesized or obtained from natural sources that could provide active components, possessing valuable properties. The 
wide occurrence of the heterocycles in bioactive natural products, pharmaceuticals, and agrochemicals has made them important synthetic targets (Musad et al., 2011). Among different five-membered heterocyclic systems, derivatives of 1,3,4-thiadiazole and 1,3,4-oxadiazole have gained importance as they constitute the structural features of many bioactive compounds (Barbuceanu et al., 2012). Thiadiazole moiety acts as "hydrogen binding domain" and "two-electron donor system". It also acts as a constrained pharmacophore. Many drugs containing thiadiazole nucleus are available on the market such as acetazolamide, methazolamide, sulfamethazole, etc. Thiadiazole acts as the third and fourth generation cephalosporins, hence can be used in antibiotic preparations (Kushwaha et al., 2012). 1,3,4-oxadiazole/thiadiazole scaffold is an important pharmacophore in agricultural science and compounds bearing this moiety often display fungicidal (Xu et al., 2011), herbicidal (Jiang et al., 2010) and insecticidal (Luo, Yang, 2007) activities.

The model of scavenging the stable DPPH radical is a widely used method to evaluate antioxidative activities in a relatively short time compared with other methods. The effect of antioxidants on DPPH radical scavenging has been thought to be due to their hydrogen donating ability (Madhu et al., 2011). The decrease in absorbance of DPPH radical is caused by antioxidants because of the reaction between antioxidant molecules and radical. This results in the scavenging of the radical by hydrogen donation.

The goal of this study was to explore bioactivity of new azole compounds, synthesized from $\mathrm{N}$-(4methylphenyl)- $\beta$-alanine hydrazide. These compounds were synthesized and investigated for the first time, therefore our objectives were: 1) to screen antioxidative activity of azole compounds, 2) to explore their influence on barley growth in vitro, 3) to investigate DPPH inhibition of barley plants, 4) to measure flavonoid amount changes in barley plants in vitro, 5) to recommend new azole compounds possessing promising biological activity for the future research in vivo.

\section{Materials and methods}

Azole derivatives, whose synthesis and characteristics have been described earlier (Tumosiene et al., 2012) were used for the tests grouped according to the structural similarities as listed in Table. Thiourea and thidiazuron (TDZ), the known growth regulators, were used in the tests as control treatments.

Table. Derivatives of pyrrole $\mathbf{A}$ and azolethiones $\mathbf{B}$ and $\mathbf{C}$, and aminodiazoles $\mathbf{D}, \mathbf{E}, \mathbf{F}, \mathbf{G}$ and $\mathbf{H}$ used for the tests

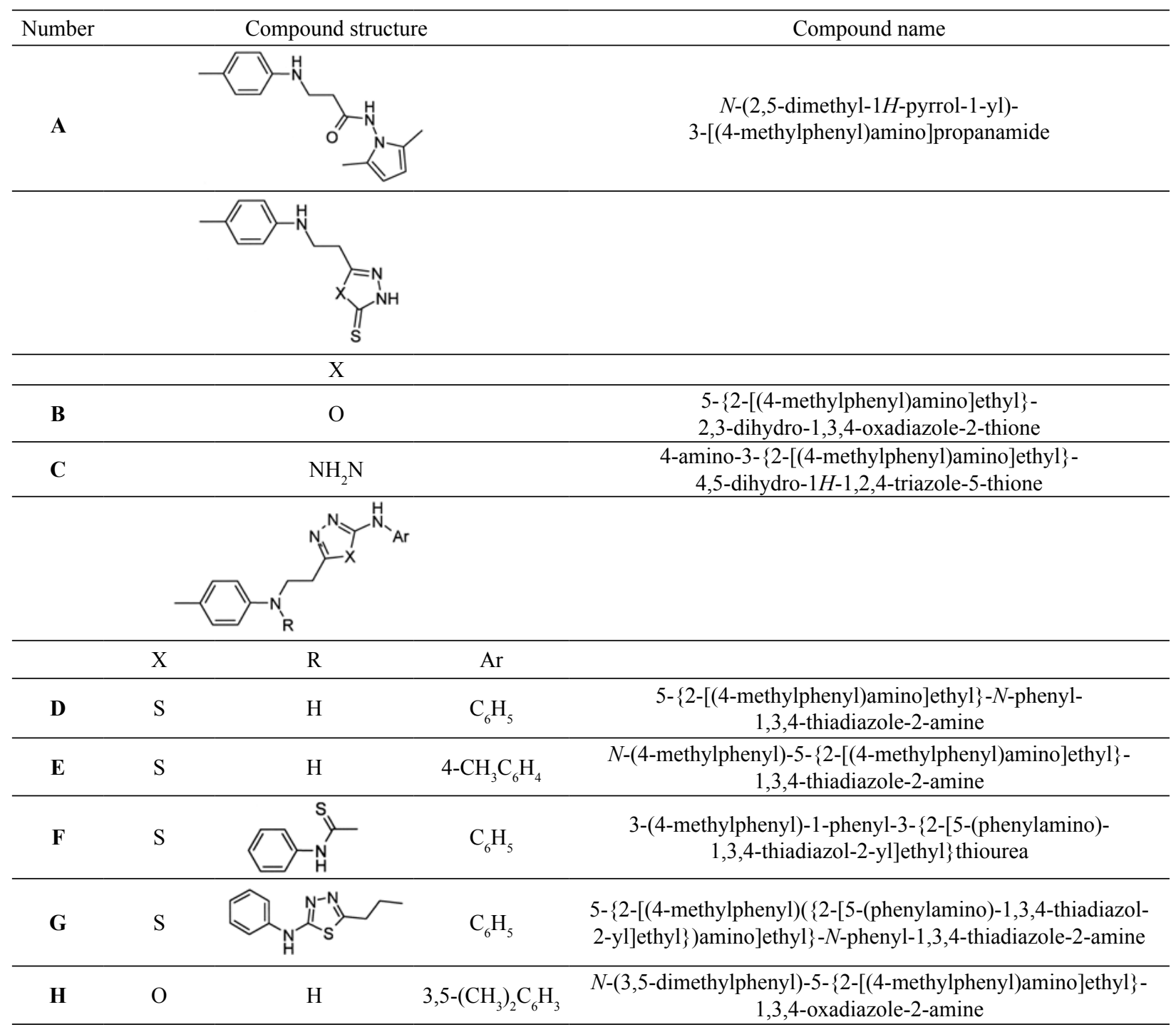


This research was carried out in 2011-2012 at Kaunas University of Technology, Faculty of Chemical Technology, Department of Organic Chemistry and Laboratory of Biotechnology. The seeds of barley cultivar 'Beatrix' (Saaten-Union GmbH, Germany) were used for the experiments. The seeds were initially washed in ethanol for $1 \mathrm{~min}$; afterwards they were washed in bleach for $20 \mathrm{~min}$ and rinsed with distilled water. After sterilization, seeds were placed in 9-cm Petri dishes (total amount 150) on filter paper, which was wetted with $3 \mathrm{ml}$ of distilled water (control sample) or solution of azole derivative. Azoles were examined at different levels of concentrations: $0.1,0.2,0.3,0.4$, and $0.5 \mathrm{mg}$ $\mathrm{1}^{-1}$. The results of experiments were compared with the ones of the control sample. Each Petri dish contained 10 seeds and was sealed with a strip of parafilm to prevent evaporation. Seeds were germinated in the dark for 7 days at room temperature $\left(22^{\circ} \mathrm{C}\right)$ (Snow, Ghaly, 2008). Each experiment was repeated three times.

Biometric measurements. The length of axial organs of 30 selected barley seedlings per treatment was measured. In order to assess the tolerance of seedlings towards azoles we applied a Wilkinson tolerance index $(\mathrm{WTI}): \mathrm{I}_{t}=\left(1_{\mathrm{me}} / 1_{c}\right) \times 100 \%$, where $1_{\mathrm{me}}$ indicates the increase in root growth in an azole solution and 1 is the increase in root growth in the control sample (Sazanova et al., 2012).

DPPH (1,1-diphenyl-2-picrylhydrazyl) radical scavenging assay. Free radical scavenging activity of compounds was measured by DPPH using the widely used method (Madhu et al., 2011). Briefly, $1 \mathrm{mM}$ solution of DPPH in ethanol was prepared, and this solution $(1 \mathrm{ml})$ was added to the solutions of tested compounds $\left(1 \mathrm{mg} \mathrm{ml}^{-1}\right.$ of dimethyl sulfoxide). The mixture was shaken vigorously and allowed to stand at room temperature for $20 \mathrm{~min}$. Afterwards, the absorbance was measured at $517 \mathrm{~nm}$ in a spectrophotometer UV-200-RS (MRC Ltd., Israel). Lower absorbance of the reaction mixture indicated higher free radical scavenging activity. The capability to scavenge the DPPH radical was calculated according to the following equation: DPPH scavenging effect $(\%)$ $=\left(\mathrm{A}_{0}-\mathrm{A}_{1} / \mathrm{A}_{0}\right) \times 100$, where $\mathrm{A}_{0}$ is the absorbance of the control reaction and $\mathrm{A}_{1}$ is the absorbance in the presence of the samples. The amount of flavonoids was determined according to $\mathrm{AlCl}_{3}$ method (Farmakopejos straipsniu rinkinys, 2001). A mixture of shredded plant material $(2 \mathrm{~g})$, acetone $(20 \mathrm{ml})$, and $28 \%$ hydrochloric acid $(2 \mathrm{ml})$ was heated under reflux for $30 \mathrm{~min}$ in a round-bottom flask. After cooling down, the hydrolizate was filtered off into a $100 \mathrm{ml}$ volumetric flask. The remaining slurry was returned to the round-bottom flask, acetone $(20 \mathrm{ml})$ was added and the mixture was heated under reflux for $10 \mathrm{~min}$. After cooling down, the hydrolizate was filtered off into the same volumetric flask as the first part. The content of the flask was diluted with acetone up to $100 \mathrm{ml}$ volume. The obtained solution $(20 \mathrm{ml})$ was diluted with water $(20 \mathrm{ml})$ and extracted with ethyl acetate: $1 \times 15 \mathrm{ml}$ and $3 \times 10 \mathrm{ml}$. The combined upper fractions were washed with water $(40 \mathrm{ml})$, filtered into $50 \mathrm{ml}$ volumetric flask and the filtrate was diluted with ethyl acetate up to $50 \mathrm{ml}$ volume. The test solution was prepared by adding $2 \mathrm{ml}$ of $\mathrm{AlCl}_{3}$ solution $\left(20 \mathrm{~g} \mathrm{l}^{-1}\right)$ to $10 \mathrm{ml}$ of the main solution and filling the flask up to $25 \mathrm{ml}$ volume by solution of acetic acid and methanol $(1: 19)$. The reference solution was prepared by adding the same acetic acid - methanol
$(1: 19)$ solution to $10 \mathrm{ml}$ of the main solution up to $25 \mathrm{ml}$ volume. After $30 \mathrm{~min}$, the absorbance was measured at $426 \mathrm{~nm}$ in a spectrophotometer UV-200-RS using the reference solution. The amount of flavonoids (X, \%) was calculated as follows: $\mathrm{X}=(\mathrm{A} \times \mathrm{k}) / \mathrm{m}$, where $\mathrm{A}$ is the absorbance of the reference solution, $\mathrm{k}-\mathrm{a}$ correction coefficient for hyperozide $(\mathrm{k}=1.25)$, and $\mathrm{m}$-mass of plant material $(\mathrm{g})$. For the test of antioxidative capacity of barley extract, DPPH radical scavenging method was used. Dry barley seedlings $(1.0 \mathrm{~g})$ with $10.0 \mathrm{ml}$ of methanol were homogenized for $10 \mathrm{~min}$ at room temperature. The homogenate was centrifuged at $10.000 \mathrm{~g}$ for $10 \mathrm{~min}$ and the supernatant was collected. Afterwards, the absorbance was measured at $517 \mathrm{~nm}$ in a spectrophotometer UV-200RS. The antioxidative activity of the barley methanol extract against the DPPH radicals was expressed as follows: DPPH scavenging effect $(\%)=\left(\mathrm{A}_{0}-\mathrm{A}_{1} / \mathrm{A}_{0}\right) \times$ 100 , where $A_{0}$ is the absorbance of the control reaction, and $A_{1}$ - the absorbance in the presence of the samples (Wang et al., 2007).

Statistical analysis. Differences between means were assessed by the Student's $t$-test at $P=0.05$. Values were expressed as mean \pm SD (Slapšyte et al., 2000).

\section{Results and discussion}

Cressierhas shownthat2-mercaptobenzothiazole and its 6-substituted derivatives display free radical scavenging activity towards DPPH (Cressier et al., 2009). $N$-(2,4-dimethylphenyl)-5-(4-nitrophenyl)-1,3,4thiadiazol-2-amine (Khan et al., 2010) and 6-phenyl3-(4-pyridyl)-1,2,4-triazolo-[3,4-b][1,3,4] thiadiazole (Cansiz et al., 2012) showed antioxidant activity. Musad synthesized and tested a series of bis(1,3,4-oxadiazole) derivatives as DPPH free radical scavengers (Musad et al., 2011). Derivative containing just phenyl ring had the best antioxidative capacity whereas the presence of either electron-donating or electron-withdrawing groups on the phenyl ring at positions 3,4,5 did not favour activity. Among the series of $N$-substituted phenyl-5-methyl-6-(5(4-substituted phenyl)-1,3,4-oxadiazol-2-yl)thieno[2,3-d] pyrimidin-4-amines, the ones containing one or two fluorine atoms and chlorine atom showed significant radical scavenging activity (Kotaiah et al., 2012).

The data obtained in this study prove that the investigated compounds exhibit very good activity as radical scavengers, indicating that they have activity as hydrogen donors.

As seen from the results presented in Figure 1, in this group of the tested compounds, 1,3,4-oxadiazole2-thione $\mathbf{B}$ showed the best radical scavenging property and its antioxidative activity was 1.28 times higher in comparison with that of thiourea. As shown in Figure 2, compounds $\mathbf{D}, \mathbf{H}$ and $\mathbf{F}$ showed the highest radical scavenging properties. Antioxidative activity of 1,3,4-thiadiazole-2-amine $\mathbf{D}$ was 1.4 times higher in comparison with that of thiourea.

Based on the data provided in Figures 1 and 2, it can be concluded, that the highest antioxidative activity was demonstrated by thiadiazole derivative $\mathbf{D}$, possessing phenyl ring at the $\mathrm{NH}$ group and no substituent at the nitrogen atom, which surpassed activity of oxadiazole derivative $\mathbf{H}$ and thiadiazole derivatives $\mathbf{F}, \mathbf{E}$ and $\mathbf{G}$, respectively, containing bulkier substituents at either of these positions. The treatment with 1,3,4-oxadiazole- 


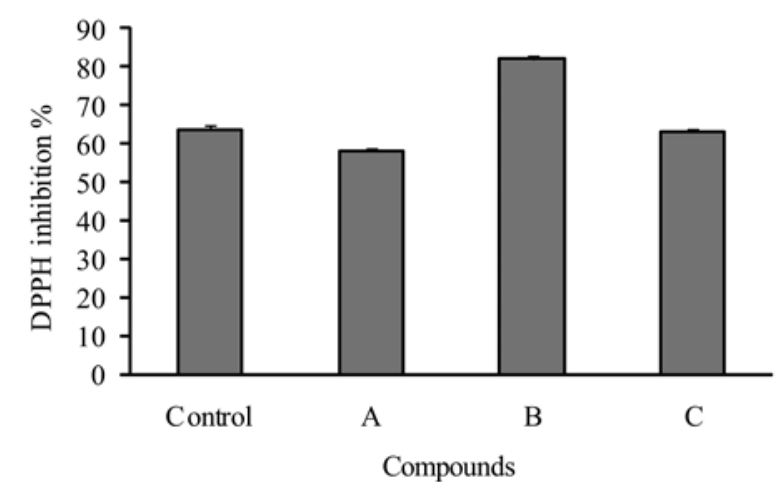

Compounds: $\quad$ A $-N$-(2,5-dimethyl-1H-pyrrol-1-yl)-3-[(4methylphenyl)amino]propanamide, $\mathbf{B}-5-\{2-[(4-m e t h y l p h e n y l)$ amino]ethyl $\}$-2,3-dihydro-1,3,4-oxadiazole-2-thione, $\quad \mathbf{C}$ 4-amino-3-\{2-[(4-methylphenyl)amino]ethyl $\}-4,5$-dihydro$1 H$-1,2,4-triazole-5-thione

Figure 1. Antioxidative properties of the control (thiourea) and azoles $\mathbf{A}, \mathbf{B}$ and $\mathbf{C}$

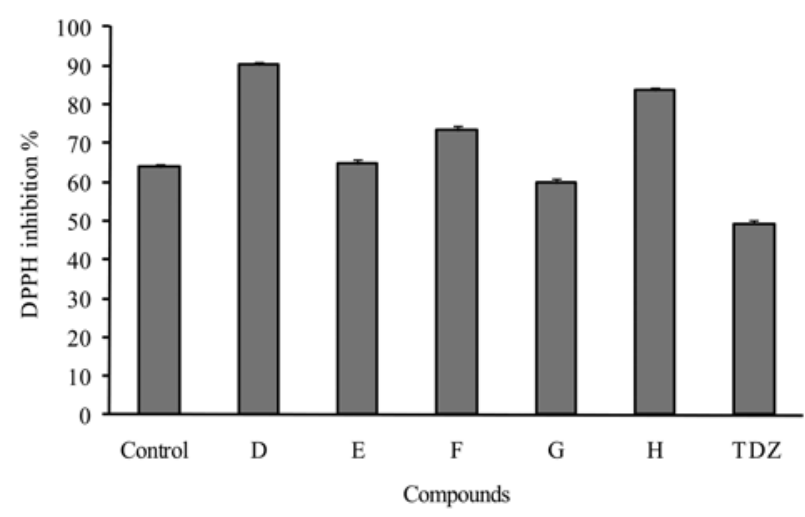

Compounds: D - 5-\{2-[(4-methylphenyl)amino]ethyl $\}-N$ phenyl-1,3,4-thiadiazole-2-amine, $\mathbf{E}-N$-(4-methylphenyl)-5$\{2-[(4-m e t h y l p h e n y l) a m i n o]$ ethyl $\}-1,3,4$-thiadiazole-2-amine, F-3-(4-methylphenyl)-1-phenyl-3-\{2-[5-(phenylamino)-1,3,4thiadiazol-2-yl]ethyl $\}$ thiourea, $\mathbf{G}-5-\{2-[(4-m e t h y l p h e n y l)$ ( $\{2$-[5-(phenylamino)-1,3,4-thiadiazol-2-yl]ethyl $\}$ )amino] ethyl $\}-N$-phenyl-1,3,4-thiadiazole-2-amine, $\quad \mathbf{H}-\mathrm{N}$-(3,5dimethylphenyl)-5-\{2-[(4-methylphenyl)amino]ethyl $\}-1,3,4-$ oxadiazole-2-amine

Figure 2. Antioxidative properties of the control (thiourea), azoles $\mathbf{D}, \mathbf{E}, \mathbf{F}, \mathbf{G}$ and $\mathbf{H}$, and thidiazuron (TDZ)

2-thione B gave better results in comparison with thiourea, whereas the effect of 1,2,4-triazole-5-thione $\mathbf{C}$ was worse than that of thiourea. It should be noted that, in all cases, the radical scavenging property of the synthesized compounds was better than that of TDZ.

Effects of azoles on length of barley shoots in vitro. In this experiment, the influence on the growth parameters of barley plants in vitro was investigated. Thiazole derivatives increase vegetative growth of plants, flowering, rooting of cuttings, inhibit falling of fruits, accelerate germination of seeds, stimulate efflorescence of buds, increase biosynthesis of ethylene, increase yield of rice (Oryza sativa L.), tomatoes (Lycopersicon Mill.), soybean (Glycine Willd), and grapes (Vitis L.).
Triazole derivatives stimulate germination of common flax (Linum usitatissimum L.) and regulate growth of tomatoes, oats (Avena L.), sugar beet (Beta vulgaris L.), and grass. Besides, 1,3,4-thiadiazole-2-amine derivatives are used in mixtures with growth regulators and fertilizers (Икрина, Колбин, 2004).

In the first group of the tested compounds (Fig. 3), the length of barley shoots was the highest when barley seeds were treated with 1,2,4-triazole-5-thione $\mathbf{C}$ $\left(0.4 \mathrm{mg} \mathrm{l}^{-1}\right)$. The barley shoots grew longer by $2.3 \mathrm{~cm}$ $(37 \%)$ in comparison with the control sample. Under the influence of $0.5 \mathrm{mg} \mathrm{l}^{-1}$ concentration solution of 1,3,4-oxadiazole-2-thione $\mathbf{B}$ barley shoots were shorter by $82.8 \%$ in comparison with the control sample. When seeds were treated with $0.1,0.2$, and $0.3 \mathrm{mg} \mathrm{l}^{-1}$ solutions of the tested compounds, the best results were obtained for pyrrole derivative A $(28.21,29.8$, and $31.41 \%$, respectively).

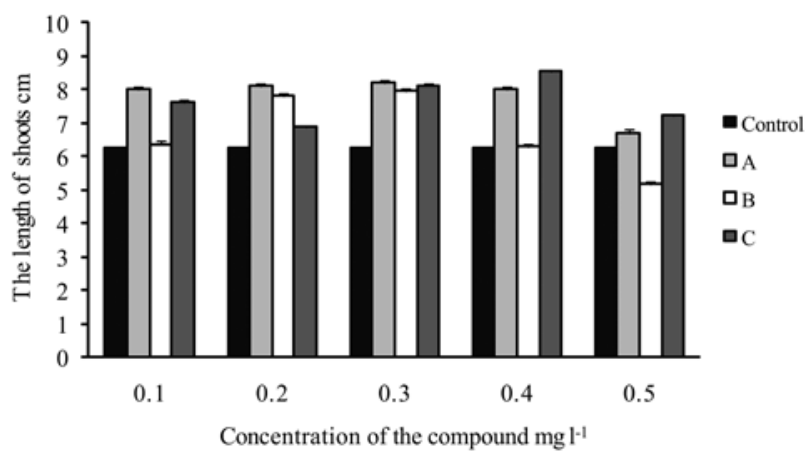

Explanations under Figure 1

Figure 3. The influence of the control (water) and compounds A, B and $\mathbf{C}$ on length of barley shoots in vitro

In the second group of the tested compounds (Fig. 4), the longest barley shoots were obtained when the seeds were treated with $N^{\prime}$-thiocarbamoyl-1,3,4thiadiazole $\mathbf{F}\left(0.1 \mathrm{mg} \mathrm{l}^{-1}\right)$. This compound had positive influence in all concentrations, except $0.5 \mathrm{mg} \mathrm{l}^{-1}$. Length of barley shoots, when seeds were treated with compound $\mathbf{F}\left(0.1 \mathrm{mg} \mathrm{l}^{-1}\right)$, was by $2.4 \mathrm{~cm}(42.7 \%)$ longer in comparison with the control sample. Thiadiazole derivative D containing the phenyl substituent at the NH group had the highest effect, when barley seeds were exposed to $0.4 \mathrm{mg} \mathrm{l}^{-1}$ concentration and increased the length of shoots by $1.24 \mathrm{~cm}(19.8 \%)$ in comparison with the control sample. Under the influence of compounds $\mathbf{G}$, $\mathbf{H}$, and TDZ, barley shoots grew shorter by 23.24, 61.7, and $40.06 \%$, respectively (at $0.5 \mathrm{mg} \mathrm{l}^{-1}$ concentration), in comparison with the control sample.

In conclusion, the results presented in Figures 3 and 4 had demonstrated, that the length of barley shoots in vitro was the most influenced by compound $\mathbf{F}$ containing phenylthioureido moiety. Slightly worse results were obtained under the influence of pyrrole derivative A, 1,2,4-triazole-5-thione $\mathbf{C}$, and 1,3,4-triazole-5-thione $\mathbf{B}$, respectively. 1,3,4-thiadiazole-2-amines $\mathbf{E}$ and $\mathbf{D}$, containing no substituent at the nitrogen atom, gave better results than 1,3,4-oxadiazole-2-amine $\mathbf{H}$ which has no substituent at the nitrogen atom as well. 


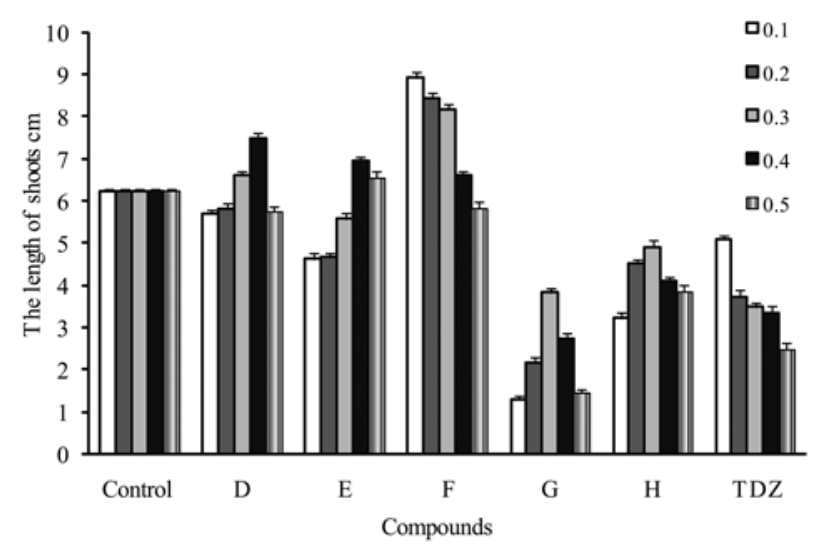

Explanations under Figure 2

Figure 4. The influence of the control (water), compounds $\mathbf{D}, \mathbf{E}, \mathbf{F}, \mathbf{G}$ and $\mathbf{H}$, and thidiazuron (TDZ) on length of barley shoots in vitro

As the results provided in Figure 5 indicate, among the first group compounds, 1,2,4-triazole-5-thione C stimulated the most growth of barley roots $\left(0.4 \mathrm{mg} \mathrm{l}^{-1}\right)$ in comparison with the control sample. This compound increased the length of barley roots by $3.7 \mathrm{~cm}(55.2 \%)$ in comparison with the control sample.

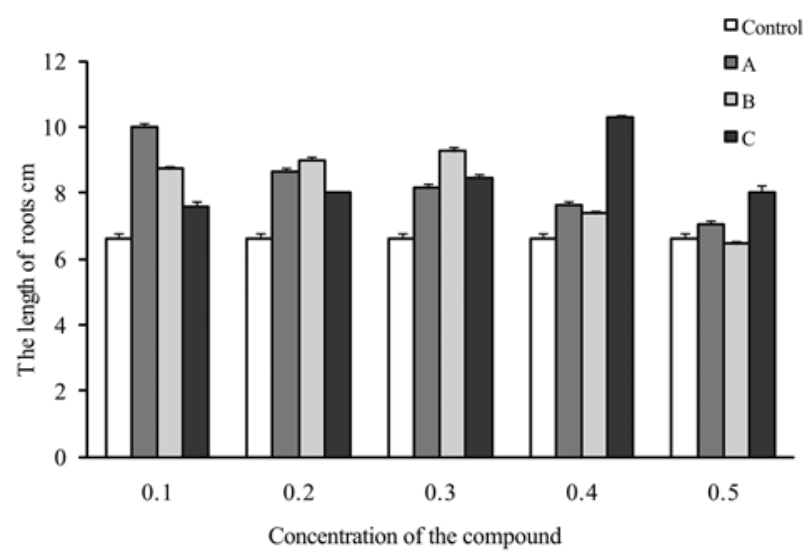

Explanations under Figure 1

Figure 5. The influence of the control (water) and compounds $\mathbf{A}, \mathbf{B}$ and $\mathbf{C}$ on length of barley roots

Among the second group compounds (Fig. 6), barley roots grew the longest when seeds were treated with $N^{\prime}$-thiocarbamoyl-1,3,4-thiadiazole $\mathbf{F}\left(0.4 \mathrm{mg} \mathrm{l}^{-1}\right)$. It increased the length of barley roots by $72.3 \%$ and they were $4.8 \mathrm{~cm}$ longer in comparison with the control sample. The second best compound was 1,3,4-thiadiazole2-amine D containing no substituent at the nitrogen atom. Under the influence of compounds $\mathbf{E}, \mathbf{G}, \mathbf{H}$, and TDZ barley shoots grew shorter by $75.64,30.25,60.51$, and $31.77 \%$, respectively (at $0.5 \mathrm{mg} \mathrm{l}^{-1}$ concentration), in comparison with the control sample.

The dependence between the structure and biological activity analysis of the data presented in Figures 3, 4, 5, and 6 indicated, that the highest growth stimulating effect has been shown by compound $\mathbf{F}$, containing 1,3,4-thiadiazole ring and phenyl substituent in it as well as phenylthiocarbamoyl substituent at the nitrogen atom. Interestingly, thiadiazole derivative $\mathbf{G}$ gave the worse results, though its structure differed from the one of compound $\mathbf{F}$ by the substituent at the nitrogen atom. If the activity of compounds $\mathbf{B}$ and $\mathbf{C}$ is compared, the effect of triazole-2-thione derivative $\mathbf{C}$ was higher than that of oxadiazole-2-thione $\mathbf{B}$.

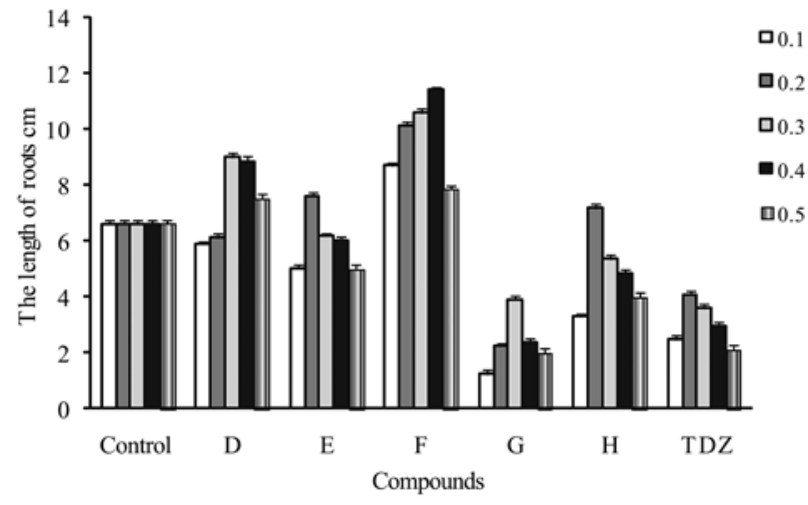

Explanations under Figure 2

Figure 6. The influence of the control (water), compounds $\mathbf{D}, \mathbf{E}, \mathbf{F}, \mathbf{G}$ and $\mathbf{H}$, and thidiazuron (TDZ) on length of barley roots

The influence of azoles on biomass of barley seedlings in vitro. The task in this part of the work was to explore the influence of azoles on biomass of barley seedlings in vitro. Triazole substituted oxathiolane compounds (Friedlander et al., 1986) and 2-(4-biphenylyl)-1-(2,4-dichlorophenyl)- and -phenyl3-(1,2,4-triazol-1-yl)-2-propanol and 4-biphenylyl2-chloro(fluoro)-phenyl-(1,2,4-triazol-1-yl-methyl)carbinol have good plant growth regulating properties (Holmwood et al., 1992).

The investigation revealed (Fig. 7) that among the first group compounds, the biomass of barley seedlings was the biggest when seeds were treated with pyrrole derivative A $\left(0.4 \mathrm{mg} \mathrm{l}^{-1}\right)$. The biomass was bigger by 64 $\mathrm{mg}(38.3 \%)$ in comparison with the control sample.

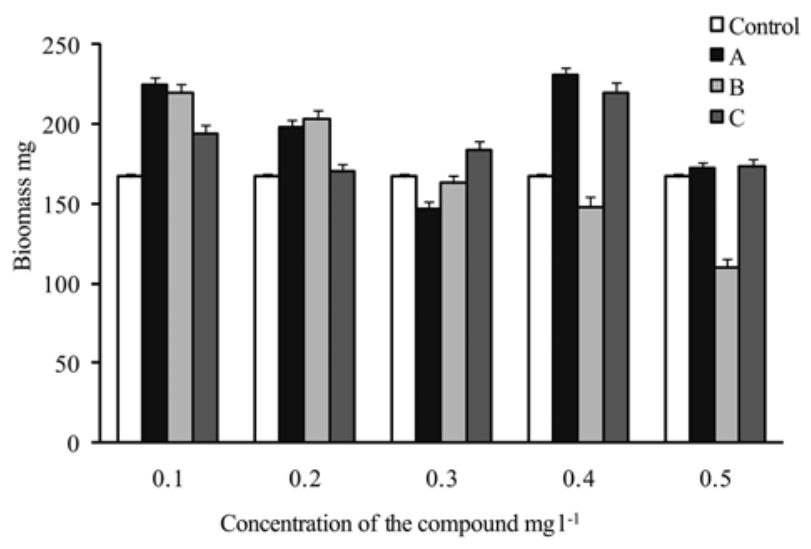

Explanations under Figure 1

Figure 7. The influence of the control (water) and compounds A, B and $\mathbf{C}$ on biomass of barley seedlings in vitro 
As seen from the results of the second group compounds presented in Figure 8, the biomass of barley seedlings was the biggest when seeds were exposed to $N^{\prime}$-thiocarbamoyl-1,3,4-thiadiazole $\mathbf{F}\left(0.1 \mathrm{mg} \mathrm{l}^{-1}\right)$. The biomass was bigger by $67 \mathrm{mg}(40.1 \%)$ in comparison with the control sample. Thiadiazole $\mathbf{D}$ gave the second best results at $0.4 \mathrm{mg} \mathrm{l}^{-1}$ concentration, whereas compounds TDZ, $\mathbf{H}$, and $\mathbf{G}$ decreased $(52.1,84.43$, and $5.99 \%$, respectively) the biomass of the barley seedlings.

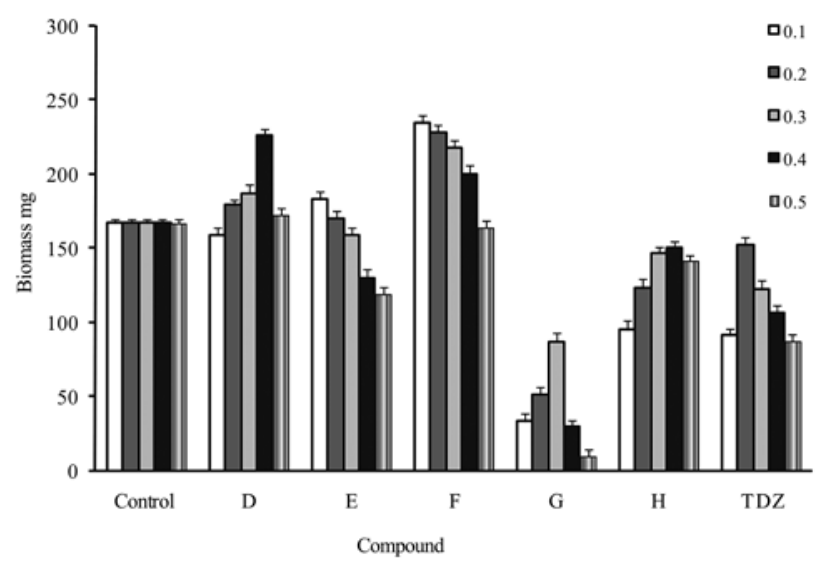

Explanations under Figure 2

Figure 8. The influence of the control (water), compounds $\mathbf{D}, \mathbf{E}, \mathbf{F}, \mathbf{G}$ and $\mathbf{H}$, and thidiazuron (TDZ) on biomass of barley seedlings in vitro

Based on the data provided in Figures 7 and 8 it can be concluded, that the biggest increase of the biomass of barley seedlings was achieved under the influence of $N^{\prime}$-thiocarbamoyl-1,3,4-thiadiazole $\mathbf{F}$ which was followed by pyrrole derivative A. Thiadiazole derivative D, whose structure differed from the one of compound F by the absence of the substituent at the nitrogen atom, showed the third best result. As it was observed in the cases described above, thiadiazole derivatives were more active than the oxadiazole derivative except compound $\mathbf{G}$ which gave the most negative result surpassed just by TDZ. The effect of triazole-2-thione derivative $\mathbf{C}$ was higher than that of oxadiazole-2-thione $\mathbf{B}$ as well.

The amount of flavonoids and DPPH inhibition. Some studies have revealed that flavonoids inhibit lipid peroxidation and low-density-lipoprotein (LDL) oxidation (Sanchez-Moreno et al., 2000; Sang et al., 2003). Moreover, in vitro experimental data also suggest that flavonoids possess antiinflammatory, antiallergic, antiviral, and anticarcinogenic properties (Nijveldt et al., 2001). The amount of flavonoids and DPPH inhibition was determined in barley seedlings, which were treated with the most active compounds $\mathbf{A}$ $\left(0.1 \mathrm{mg} \mathrm{l}^{-1}\right), \mathbf{C}\left(0.4 \mathrm{mg} \mathrm{l}^{-1}\right)$ and $\mathbf{F}\left(0.1 \mathrm{mg} \mathrm{l}^{-1}\right)$.

Results showed (Fig. 9) that the highest amount of flavonoids was in barley seedlings in vitro, which were treated with $N^{\prime}$-thiocarbamoyl-1,3,4-thiadiazole F $\left(0.1 \mathrm{mg} \mathrm{l}^{-1}\right)$. This compound increased the amount of flavonoids 11.25 times in comparison with the control.

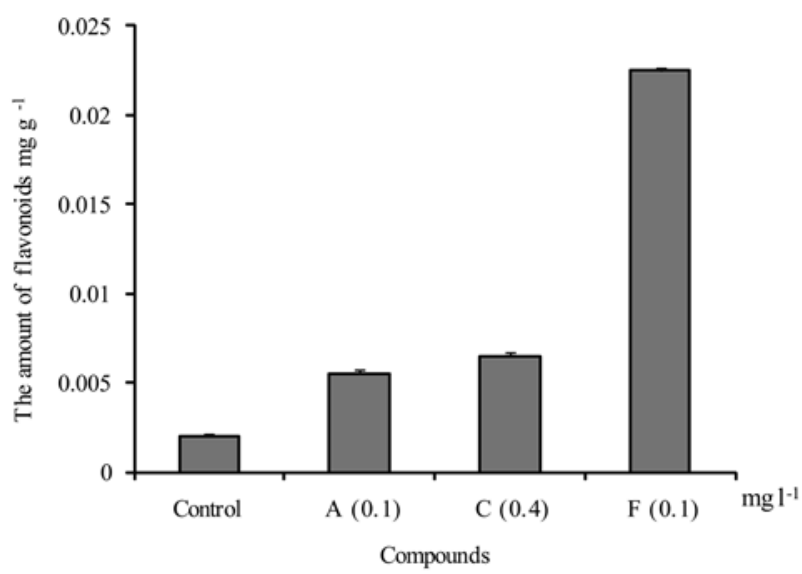

Compounds: A - N-(2,5-dimethyl-1H-pyrrol-1-yl)-3-[(4methylphenyl)amino]propanamide, $\mathbf{C}-$ 4-amino-3-\{2[(4-methylphenyl)amino] ethyl $\}-4,5$-dihydro- $1 H$-1,2,4triazole-5-thione, F - 3-(4-methylphenyl)-1-phenyl-3-\{2-[5(phenylamino)-1,3,4-thiadiazol-2-yl]ethyl $\}$ thiourea.

Figure 9. The amount of flavonoids in barley seedlings

Under the influence of the same $N^{\prime}$-thiocarbamoyl1,3,4-thiadiazole $\mathbf{F}\left(0.1 \mathrm{mg} \mathrm{l}^{-1}\right)$ the highest antioxidative activity was achieved for the barley seedlings (Fig. 10). This compound increased antioxidative activity of barley seedlings 1.1 times in comparison with the control sample.

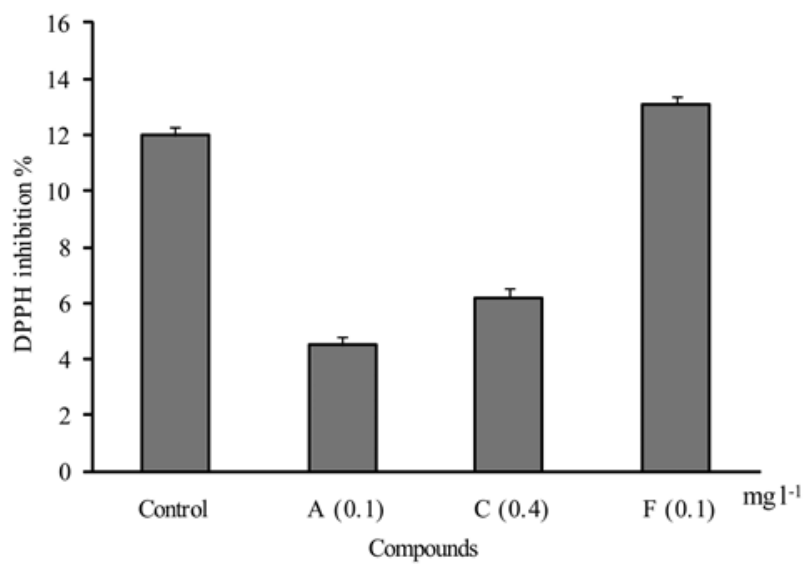

Explanations under Figure 9

Figure 10. Antioxidative activity of barley seedlings

\section{Conclusions}

1. It was determined that among the tested azole derivatives, compounds containing 1,3,4-thiadiazole moiety were the most active ones. Biological activity of the majority of the tested azole derivatives was better than that of thidiazuron (TDZ).

2. 5- $\{2-[(4-m e t h y l p h e n y l)$ amino $]$ ethyl $\}-N$ phenyl-1,3,4-thiadiazole-2-amine (D) was found to be significant scavenger of free radicals.

3. 3-(4-methylphenyl)-1-phenyl-3- $\{2-[5-$ (phenylamino)-1,3,4-thiadiazol-2-yl]ethyl $\}$ thiourea (F), i.e. compound, whose structure differed from that 
of compound $\mathbf{D}$ by phenylthiocarbamoyl substituent in the amino group, was identified as the best growth stimulator.

4. The highest amount of flavonoids was accumulated under the influence of the same 3-(4-methylphenyl)-1-phenyl-3-\{2-[5-(phenylamino)1,3,4-thiadiazol-2-yl] ethyl $\}$ thiourea $(\mathbf{F})$.

5. Thiadiazole derivatives $\mathbf{D}$ and $\mathbf{F}$ are recommended as promising growth regulating agents for the future research in the mixtures with fertilizers under field conditions.

\section{Acknowledgements}

The authors are grateful to Institute of Agriculture, Lithuanian Research Centre for Agriculture and Forestry for the barley seeds.

Received 21122012

Accepted 26062013

\section{References}

Andersen Ø. M., Markham K. R. 2006. Flavonoids. Chemistry, Biochemistry and Applications. Boca Raton, USA, $1212 \mathrm{p}$.

Barbuceanu S. F., Saramet G., Almajan G. L., Draghici C., Barbuceanu F., Bancescu G. 2012. New heterocyclic compounds from 1,2,4-triazole and 1,3,4-thiadiazole class bearing diphenylsulfone moieties. Synthesis, characterization and antimicrobial activity evaluation European Journal of Medicinal Chemistry, 49: 417-423 http://dx.doi.org/10.1016/j.ejmech.2012.01.031

Cansiz A., Cetin A., Orek C., Karatepe M., Sarac K., Kus A., Koparir P. 2012. 6-Phenyl-3-(4-pyridyl)-1,2,4-triazolo$[3,4-b][1,3,4]$ thiadiazole: synthesis, experimental, theoretical characterization and biological activities. Spectrochimica Acta, Part A: Molecular and Biomolecular Spectroscopy, 97: 606-615 http://dx.doi.org/10.1016/j.saa.2012.07.016

Cressier D., Prouillac C., Hernandez P.,Amourette C., Diserbo M., Lion C., Rima G. 2009. Synthesis, antioxidant properties and radioprotective effects of new benzothiazoles and thiadiazoles. Bioorganic and Medicinal Chemistry, 17 (14): 5275-5284 http://dx.doi.org/10.1016/j.bmc.2009.05.039

Farmakopejos straipsnių rinkinys. 2001 [Collection of articles on pharmacopoeia]. The State Medicines Control Agency under the Ministry of Health of the Republic of Lithuania Kaunas, 203 p. (in Lithuanian)

Friedlander B. T., Blem A. R., Davis R. A., Walker D. L. 1986. Azole-substituted oxathiolanes as pesticides and plant growth regulators. EP Patent 224998

Gerhäuser C. 2005. Beer constituents as potential cancer chemopreventive agents. European Journal of Cancer, 41 1941-1954 http://dx.doi.org/10.1016/j.ejca.2005.04.012

Hall R. D. 1999. Plant cell culture protocols. Methods in Molecular Biology. Totowa, USA, $421 \mathrm{p}$. http://dx.doi.org/10.1385/1592595839

Holmwood G., Regel E., Jager G., Buchel K. H., Frohberger P. E., Brandes W., Lurssen K. 1992. Ether derivatives of substituted 1-hydroxylalkyl-azoles as fungicides and plant growth regulators. U.S. Patent 5141553

Jiang L., Tan Y., Zhu X., Wang Z., Zuo Y., Chen Q., Xi Z., Yang G. 2010. Design, synthesis, and 3D-QSAR analysis of novel 1,3,4-oxadiazol-2(3H)-ones as protoporphyrinogen oxidase inhibitors. Journal of Agricultural and Food Chemistry, 58: 2643-2651

http://dx.doi.org/10.1021/jf9026298
Khan I., Ali S., Hameed S., Rama N. H., Hussain M. T., Wadood A., Uddin R., Ul-Haq Z., Khan A., Ali S., Choudhary M. I. 2010. Synthesis, antioxidant activities and urease inhibition of some new 1,2,4-triazole and 1,3,4-thiadiazole derivatives. European Journal of Medicinal Chemistry, 45: 5200-5207 http://dx.doi.org/10.1016/j.ejmech.2010.08.034

Kotaiah Y., Harikrishna N., Nagaraju K., Rao C. V. 2012. Synthesis and antioxidant activity of 1,3,4-oxadiazole tagged thieno[2,3-d] pyrimidine derivatives. European Journal of Medicinal Chemistry, 58: 340-345 http://dx.doi.org/10.1016/j.ejmech.2012.10.007

Kushwaha N., Kushwaha S. K. S., Rai A. K. 2012. Biological activities of thiadiazole derivatives: a review. International Journal of Chemtech Research, 4 (2): 517-531

Luo Y. P. Yang G. F. 2007. Discovery of a new insecticide lead by optimizing a target-diverse scaffold: tetrazolinone derivatives. Bioorganic and Medicinal Chemistry, 15: 1716-1724 http://dx.doi.org/10.1016/j.bmc.2006.12.002

Madhu L. N., Suchetha K. N., Sarojini B. K. 2011. In vitro and in vivo antioxidant property of sulphydryl group containing 1,2,4-triazole derivative. Drug Invention Today, 3 (12): 297-300

Markham K. R., Mitchell K. A. 2003. The mis-identification of the major antioxidant flavonoids in young barley (Hordum vulgare) leaves. Journal of Biosciences, 58: 53-56

Musad E. A., Mohamed R., Saeed B. A., Vishwanath B. S., Rai L. K. M. 2011. Synthesis and evaluation of antioxidant and antibacterial activities of new substituted bis(1,3,4oxadiazoles), 3,5-bis(substituted) pyrazoles and isoxazoles. Bioorganic and Medicinal Chemistry Letters, 21 (12): 3536-3540 http://dx.doi.org/10.1016/j.bmcl.2011.04.142

Nijveldt R. J., Nood van E., Hoorn van D. E. C., Boelens P. G., Norren van K., Leeuwen van P. A. M. 2001. Flavonoids: a review of probable mechanisms of action and potential applications. American Journal of Clinical Nutrition, 74: 418-425

Ragaee S., Abdel-Aal E.-S. M., Noaman M. 2006. Antioxidant activity and nutrient composition of selected cereals for food use. Food Chemistry, 98: 32-38 http://dx.doi.org/10.1016/j.foodchem.2005.04.039

Sanchez-Moreno C., Jimenez-Escrig A., Saura-Calixto F. 2000. Study of low-density lipoprotein oxidizability indexes to measure the antioxidant activity of dietary polyphenols. Nutrition Research, 20: 941-953 http://dx.doi.org/10.1016/S0271-5317(00)00185-8

Sang S., Tian S., Wang H., Stark R. E., Rosen R. T., Yang C. S., Ho C. T. 2003. Chemical studies of the antioxidant mechanism of tea catechins: radical reaction products of epicatechin with peroxyl radicals. Bioorganic and Medicinal Chemistry, 11: 3371-3378 http://dx.doi.org/10.1016/S0968-0896(03)00367-5

Sazanova K. A., Bashmakov D. I., Brazaityte A., Bobinas C.., Duchovskis P., Lukatkin A. S. 2012. The effect of heavy metals and thidiazuron on winter wheat (Triticum aestivum L.) seedlings. Zemdirbyste-Agriculture, 99 (3): 273-278

Slapšytė G., Paulauskas A., Morkūnas V. 2000. Genetikos praktikumas. Vilnius, 82 p. (in Lithuanian)

Snow A. M., Ghaly A. E. 2008. Use of barley for the purification of aquaculture wastewater in a hydroponics system. American Journal of Environmental Sciences, 4 (2): 89 $102 \mathrm{http} / /$ dx.doi.org/10.3844/ajessp.2008.89.102

Tumosienė I., Jonuškienė I., Kantminienė K., Beresnevičius Z. J. 2012. The synthesis of azole derivatives from 3-[(4-methylphenyl)amino]-propanehydrazide and its $N^{\prime}$-phenylcarbamoyl derivatives, and their antibacterial activity. Monatshefte für Chemie - Chemical Monthly, 143: $1441-1450$ 
Ünver Y., Meydanal S., Sancak K., Ünlüer D., Ustabas R., Dügdü E. 2011. Synthesis, crystal structure, and antioxidant properties of novel 1,2,4-triazol-5-ones containing 3,4-dimethoxyphenyl and 3,4-dihydroxyphenyl moiety. Turkish Journal of Chemistry, 35: 265-277

Xu W., Yang S., Bhadury P., He J., He M., Gao L., Hu D., Song B. 2011. Synthesis and bioactivity of novel sulfone derivatives containing 2,4-dichlorophenyl substituted 1,3,4-oxadiazole/thiadiazole moiety as chitinase inhibitors. Pesticide Biochemistry and Physiology, 101 (1): 6-15 http://dx.doi.org/10.1016/j.pestbp.2011.05.006
Wang Y. L., Wang X. D., Zhao B., Wang Y. C. 2007. Enhancing antioxidative capacity of lepidium meyenii calli by addition of methyl salicylate to culture medium. Acta Physiologiae Plantarum, 29: 417-423 http://dx.doi.org/10.1007/s11738-007-0050-5

Yu Y. M., Wu C. H., Tseng Y. H., Tsai C. E., Chang W. C. 2002. Antioxidative and hypolipidemic effects of barley leaf essence in a rabbit model of atherosclerosis. Japanese Journal of Pharmacology, 89: 142-148 http://dx.doi.org/10.1254/jjp.89.142

Икрина М. А., Колбин А. М. 2004. Регуляторы роста и развития растений. Москва, 695 с. (in Russian)

ISSN 1392-3196 / e-ISSN 2335-8947

Zemdirbyste-Agriculture, vol. 100, No. 3 (2013), p. 261-268

DOI 10.13080/z-a.2013.100.033

\title{
Azolų antioksidacinis aktyvumas ir jų įtaka paprastojo miežio (Hordeum vulgare L.) daigams bei flavonoidų kaupimui
}

\author{
I. Jonuškienė, I. Tumosienė, K. Kantminienė, K. Rutkauskas, Z. J. Beresnevičius
}

Kauno technologijos universitetas

\section{Santrauka}

Tyrimo tikslas - ištirti azolų antioksidacini aktyvumą ir ju ịtaką miežiu augimui in vitro bei flavonoidu kiekiui. Iš tirtų junginių didžiausiu antioksidaciniu aktyvumu pasižymejjo 5-\{2-[(4-metilfenil)amino]etil\}- $N$-fenil-1,3,4tiadiazol-2-aminas. Nustatyta, kad didžiausią miežių augimą skatinanti poveikị turèjo 3-(4-metilfenil)-1-fenil-3$\{2$-[5-(fenilamino)-1,3,4-tiadiazol-2-il]etil $\}$ tiokarbamidas. Šio junginio tirpale $\left(0,1 \mathrm{mg} \mathrm{l}^{-1}\right)$ auginti miežių ūgliai buvo $42,7 \%$ aukštesni, o miežių, apdorotų šio junginio $0,4 \mathrm{mg} \mathrm{l}^{-1}$ koncentracijos tirpalu, šaknys buvo $72,3 \%$ ilgesnès, lyginant su kontroliniu variantu. Didžiausias antioksidacinis daigų aktyvumas pasireiškè miežiuose, augintuose 3-(4-metilfenil)-1-fenil-3-\{2-[5-(fenilamino)-1,3,4-tiadiazol-2-il]etil $\}$ tiokarbamido tirpale $\left(0,1 \mathrm{mg} \mathrm{l}^{-1}\right)$. Dauguma tirtų junginių buvo aktyvesni nei žinomas augimo reguliatorius tidiazuronas (TDZ).

Reikšminiai žodžiai: biologinis aktyvumas, metabolitai, oksadiazolas, tiadiazolas. 